Linguistik Terapan 17 (3) (2020): 273-280

Jurnal Linguistik Terapan Pascasarjana

Available online

http://jurnal.unimed.ac.id/2019/index.php/JLT-Unimed

\title{
GRAMMATICAL ERROR OF SPEECH BY STUDENTS IN BILINGUAL PROGRAM OF MA'HAD AL JAMI'AH UIN NORTH SUMATRA
}

\author{
Riyah Shibha Nasution \\ Rahmad Husein \\ Anni Holila Pulungan \\ English Aplied Linguistic Program \\ Postgraduate Program-Universitas Negeri Medan
}

Diterima September 2020; Disetujui Oktober 2020; Dipublikasikan Desember 2020

\begin{abstract}
This study investigates the types of grammatical errors produced by Arabic learners in English. Bilingual program is a condition that the students speak both English and Arabic languages in their daily communication. The researcher used descriptive qualitative research in conducting this study. The data are bilingual students' utterances consisting of grammatical errors in daily communication. The utterances consisted of words, phrases, clauses and sentences. The prior aim in this research is to describe the types of grammatical errors since there are two kinds of grammatical errors namely morphological errors and syntactical errors.
\end{abstract}

Keywords: Grammatical Error, Bilingualism, English, Arabic language, Speech

How to Cite: Shibha Nasution, Riyah. (2020). Grammatical Error of Speech by Students in Bilingual Program of Ma'had Al Jami'ah Uin North Sumatra. Jurnal Linguistik Terapan-Pascasarjana Unimed. 17 (3): 273-280.

ISSN: 2407 - 7410

\section{INTRODUCTION}

Recently, people are considered to use two languages in their communication. This case is claimed as the phenomenon of bilingualism. The phenomenon of bilingualism is seen as the way to enhance the capability of personal quality. Being bilingual means that being able to have the competence in speaking two languages at the time. 
In the popular view, Abutelabi and Weekes (2014) explained that a bilingual speaker may be someone with different levels of proficiency in the two languages, using the two languages in different contexts or learning a new language due to educational requirements, immigration, or other business and life demands. This definition, a bilingual individual is not only necessarily someone who has acquired both languages from birth, or early in life, but also one who learns a second language (L2) later in life. Then, Brice (2009) proposes that a bilingual is defined as the ability to speak, listen, tread and or write in more than one language with varying degrees of proficiency.

By mastering more than one language in our communication it helps us to understand other languages easier than people who only understand one language in the whole of their communication. this view highly supported by the explanation that explained by Hudson (2007) while he stated that with the use of two languages, students gain the increase of cognitive development as they perform more divergent and creative thinking. More specifically, Fromklin and Hyams(2007) stated that bilinguals also hold a greater awareness of meaning and structure in language because they are familiar with two languages from which they can make generalizations about the characteristics of languages instead of one. as cited above, bilingualism direct us to understand the language that we use easier because of activation in our cognitive to notice the languages particularly in tem of grammatical level.

Ma'had Al Jami'ah UIN SU, for instance, is the institution which is applied the bilingual program while the languages are English and Arabic language. This Ma'had (boarding school) used two languages in their all activities including their teaching class program like studying Tahsin (enhancing) and Tahfidz (memorizing) Quran. The students have to speak English and Arabic in daily communication. Beside, the turn time taking is provided to make students focus in what language they used. They have to speak English and Arabic in certain week. One week for English and one week for Arabic. In the language week, students must speak English and Arabic languages; it depends on the week of language.

In relation to the bilingualism particularly English and Arabic language, Ahmad (2017) found that there was no significantly differences both English and Arabic. The different items can be found in the language transparency, phonology and morphology terms. It is also supported by the findings in Bader and Mustafa (2009) that denoted the position of foreign language can influence our understanding in mastering another foreign language. It is actually two languages are integrated each other. In order to say that students who have their basic in one foreign language actually help their understanding in another foreign language. 
In fact, the students in Ma'had Al Jami'ah are mostly from boarding school (Pesantren) so that they have a basic in understanding Arabic language. Meanwhile, it does not influence to the students in using English well. The students mostly produced the errors in the communication when they speak by using English.

Based on the background of the study, the problem is formulated as the following:

What types of grammatical errors of speech are produced by students in bilingual program of Ma'had Al Jami' ah UIN North Sumatra?

Moreover, the grammatical error is seen as the condition that produced by language user in every single context communication without using the function of the pattern in the language itself so that the idea, information and lesson are not conveyed by the listener.

In the term of grammar, Feng (2013) highlighted that grammar can be viewed in the two kinds of grammar since it can be seen as the functional grammar and formal grammar. Functional grammar, based on systemic linguistics, emphasizes the way spoken and written language operates in different social situations. In particular, it is very useful in showing how texts work beyond the level of the sentence, how different texts are structured, and how language varies to suit the purpose of the users. It takes on a descriptive approach and focuses on groups of words that function to make meanings.

\section{A. TYPES OF GRAMMATICAL ERRORS}

Obviously, Mardijono (2003) classified grammatical errors refer to the two main clause parts, they are: morphological errors and syntactical errors.

\section{English and Arabic languages}

Based on the same position as the foreign language in Indonesia, Mohammad (2015) explained that similarities between the two languages in comparison. In Arabic, students study the conditionals as hypothetical and come in an if-clause and a main clause. In English, it comes as a main clause and a subordinate clause that is similar to the syntactic structure of Arabic. This makes it easy to learn conditionals by transferring the knowledge from Arabic.

English has two kinds of 'conditional if' sentences, the unreal conditional and the real conditional. The 'unreal conditional if' is translated as /law/ in Arabic, whereas the 'real conditional if' is translated as /Iða:/ and /in/. That is, the verb of the conditional clause which follows all of the above mentioned Arabic particles are always in the past tense (Khalil: 1999), for example: Iða: ðahab is literally translated as 'If he went', however in English it would read 'If he goes'. 'insaalanifa-saujeebuhu' is literally translated as 'If he asked me 
then I will answer him.', however in English it would read as 'If he asks me I will answer him.'

Furthermore, in English the 'conditional unreal if' is followed by a past tense clause, followed by 'would' indicating unreal conditional, whereas in Arabic, the only indicator is the word /law/. Hence, Arab learners tend to omit the word 'would' in speaking and writing. 'If they were here, they would pay her.' is often produced by Arabic speakers as 'If they were here, they pay her', omitting 'would' as it is not used in this context in Arabic. Another common feature between Arabic and English syntax is the use of conjunctions. In Arabic, students can produce correct sentences using (and, but and so) that has the same meaning when they transfer it literally in English. An example of simple connectives is 'and' which is translated as /wa/ in Arabic. As in English the Arabic connective 'wa' is used to connect both words and clauses.

However, in English, when listing a number of words, 'and' is used to connect the last word in the list of words, whereas in Arabic, /wa/ is used before every subsequent word following the first word in the list, for example: English: The man, woman and child was killed. Arabic: QutilaArrajlwalimra a wad tifl.

On the other hand, In Arabic, the adjective-noun order is noun + adjective (qalamazraq) while in English the order is (adjective + noun) so that it instead of blue pen.

Second, another problem that may face due to different syntactic features of Arabic and English is that Arabic is a null-subject language. In Arabic, it syntactically correct to produce nominal clauses and verbal clauses while in English only verbal clauses are correct such as (sā'id 'ayrak, yusā'idk), the correct equivalent in English is (help others so they help you). However, it will translate it to (help others, so help you). Dropping the subject here is clearly due to the Arabic syntactic feature that accepts it as correct without the subject. The subject in Arabic structure is covert while in English structure the subject is overt and comes before the verb, this is another word order issue. In Arabic they can drop copula be creating nominal correct statements such as (Akhi muhandis) while in English it is essential to use the copula be to produce such a statement (My brother is an engineer).

\section{METHOD}

The research design that will be used in this research is qualitative research. In line with this case, Djajasudarma (2006:16) elaborated that description in qualitative design is a description of the characteristics the data accurately in accordance with the nature of the data 
itself. The qualitative research will be used in this research since the data refer to the form of quality of verbal not in the form of number.

The data of this study are bilingual students' utterances in bilingual program consisting of grammatical errors in the daily communication. Hence, the utterances consisted of words, phrases, clauses and sentences. The source of the data in this study is Ma'had Al Jami'ah UIN North Sumatra students.

The source of data in this study is six students. They are selected by purposive sampling with the following criteria as follows: (1) the students who have good capability in mastering Arabic language since their background education were graduated from boarding school. This can be seen from the list report by the English council development program in Mahad Jamiah UIN North Sumatra in academic year 2018/2019 (2) the students who use English and Arabic in their daily communication.

Bogdan and Biklen (1992:31) stated that 'the researcher is as the key instruments. It means that everything is controlled by the researcher. Observation sheet and guided interview are the supporting instrument of data collection in this paper. This way will be used to examine the syntactical error of speech by students in bilingual program of Ma'had A1 Jami'ah North Sumatra.

\section{RESULT AND DISCUSSION}

Here are the examples of the data by the students of bilingual program in Ma'had Al Jami'ah UIN North Sumatra.

Conversation I:

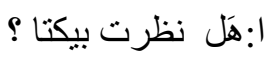

Have you found my book?

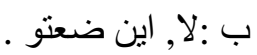

No, I have not. Where did you put it?

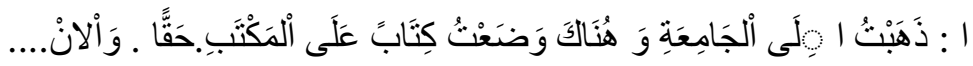
I went to the class and I put my book on my table. Oh really

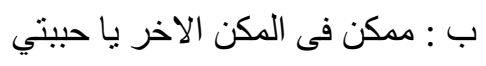

It could be in other places, dear. 
This preliminary data, the students communicate by using Arabic language syntactically since it can be seen from the structure of Arabic language that they used correctly. In order to say that the student rarely produce the errors in speaking Arabic language. In addition, some terminologies of grammatical in English existed in Arabic language. Therefore, the syntactical rules of English also happen in Arabic language such as verb agreement and verb tense case. It can be proved from the conversation above as follows: the word Dzahabtu derives from dzahaba-yadzhabu, the sign of letter $T a$ is referred to the past tense in Arabic and it is known as the Fi'il Madhi. The word of Satata'allamu derives from Ta'allama-Yata'allamu, the sign of letter $S a$ is referred to the future tense while in Arabic language it is known as the Fi'il Mudhori'.

\section{Conversation II}

A: Where my cloth?

B: Where you put?

A: ...I finish take bath, I put my cloth in here. You take it?

B: No, I have many cloth. You look at the other place. I think you forget just now.

A: I think so. Thank you.

Based on the preliminary data above, the students did their conversation syntactically in English. The case of this conversation mostly seems quite different with the conversation that the students spoke in Arabic language. The errors in this preliminary data ease to find out as follows:

Where my cloth instead of where is my cloth. The word of using is as the linking verb not existed. By following the term of syntax it should be put in the word of where so that the interrogative sentence in this case will be sentence grammatically. Then, the sentence where you put instead of where did you put. The word of using did is as the verb agreement not existed more. By following the term of syntax it should be put in the word after where so that the interrogative sentence in this case will be sentence syntactically. I finish take bath instead of I have taken bath. In this case, the student does not aware in using the form of verb phrase. This sentence actually refers to the present perfect tense since it consist of have followed by past participle.

You take it instead of have you taken it. In relation to this case, the student does not aware in using the form of verb in producing the interrogative sentence. The students frequently omit the word of verb agreement in the interrogative sentence. I have many cloth instead of I have many clothes. The student does not aware in using singular and plural formation in a sentence. It seems that the pattern in singular and plural is strongly misused in 
this sentence. You forget just now instead of you have forgotten. The student does not aware in using the form of verb phrase. This sentence actually refers to the present perfect tense since it consist of have followed by past participle.

\section{Conversation I}

A: I want to tell you. Nisa is not here. Her body sick and she want check up.

B: oh my god, how many days that she wants to go home? Has she told to you?

A: yes, but I say yesterday execuse to you.

B: I don't her actually.

A: she by glasses, she only just now excuse to me. But I say to she excuse to you.

B: okay, I am waiting for her.

\section{Conversation II}

A: do you feel okay here?

$\mathrm{B}$ : yes, interesting for me in memorize the quran

A: it makes you feel comfort here, there are many trees

B: absolutely, I not sleepy

A: how much we pay in the canteen for lunch?

B: please your repeat your asking.

A: how much we pay in the canteen for lunch?

B: oh, eighteen thousand

Based on the data above, it found that mostly students produced the grammatical errors referred to the term of syntactical errors in part of verb phrase.

\section{REFERENCES}

Abutalebi, J., \&Weekes, B. (2014). Editorial: The cognitive Neurology of Bilingualism in the Age of Globalization. Behavioral Neurology. Vol : 2014 : 2-4. Hindawi Publishing Corporation.

Absi, Abu S. (2016). History of Islam, an Encyclopedia of Islamic Histrory. https://historyofislam.com/contents/the-modern-age/the-arabic-language/.

Ahmad, S, A. (2017). The Self-Concept of Arabic and English Speaking Bilingual and Monolingual Pupils with Specific Literacy Difficulties. University of Exeter: Doctor of Philosophy in Education.

Alduais, A, M. (2012). Simple Sentence Structure of Standard Arabic Language and Standard English Language: A Contrastive Study. Macrothink Institute: International Journal 
of Linguistics . vol. 4. No. 4: 504-507. Saudi Arabia: Department of English, King Saud University.

Alkhafji, A,R. (1972). Description And Contrastive Analysis Of Tense And Time In English And Arabic. PhD Thesis: University of Glosgow.

Baker, C. (2001). Foundations of Bilingual Education and Bilingualism.Third Edition. UK: Multilingual Matters.

Bloomfield, L. (1935). Language (Revised edition). London: Allen \& Unwin.

Bogdan, Robert C and Biklen, Sari Knopp. (1992) Qualitative Research for Education; An Introduction to Theory and Method. Boston: Allyn and Bacon.

Budiawan. (2010). Unpublished Thesis. Pengaruh Sikap Bahasa dan Motivasi Belajar Bahasa terhadap Prestasi Belajar Bahasa Arab dan Bahasa Inggris siswa Aliyah sePalembang, FIB, UI.

Choiriyah,B. (2007). Syntactical Errors in Thesis Proposals on Syntax Study Written by the students of English Letter and Language Department of the State Islamic University of Malang. A thesis.UIN:Malang.

Chomsky, Noam. (2002). Syntactic Structures. Berlin: Walter de Gruyter GmbH.

Cummins, J. (1981). The Role of Primary Language Development in Promoting Educational Success For Language Minority Students. In Schooling and Language Minority Students: A Theoretical Framework. California State University, Los Angeles: Evaluation, Dissemination and Assessment Center, 3-49.

Desmet, T., and duck, W. (2007). language and linguistic Compass: Bilingual Language Processing. Blackwell Publishing ltd: Journal Compilation.

Dulay, H., Burt, M., \& Krashen, S. (1982). Language two. Oxford, UK: Oxford University Press.

Duyck, W. (2005). Translation and associative priming with cross-lingual pseudohomophones: evidence for nonselective phonological activation in bilinguals. Journal of Experimental Psychology: Learning Memory and Cognition 31.1340-59. 